ReVISTA de BIOLOGía TROPICAL

\title{
Facilitative behavioral interactions between deepwater piscivores at Isla del Coco National Park and Las Gemelas Seamount, Costa Rica
}

\author{
Peter J. Auster ${ }^{1,2}$, Astrid Sánchez-Jiménez ${ }^{3}$, Jesús A. Rodríguez-Arrieta ${ }^{3,4,5}$, Andrés J. Quesada ${ }^{3}$, \\ Cinthya Pérez ${ }^{3}$, Beatriz Naranjo-Elizondo ${ }^{3}$, Schmulik Blum ${ }^{6} \&$ Jorge Cortés ${ }^{3,5}$ \\ 1. University of Connecticut, Northeast Undersea Research, Technology \& Education Center and Department of Marine \\ Sciences, 1080 Shennecossett Rd., Groton, Connecticut06340 USA; pauster@searesearch.org \\ 2. Sea Research Foundation - Mystic Aquarium, 33 Coogan Blvd., Mystic, Connecticut 06355 USA. \\ 3. Centro de Investigación en Ciencias del Mar y Limnología (CIMAR), Ciudad de la Investigación, Universidad de \\ Costa Rica, San Pedro, San José 11501-2060, Costa Rica; jorge.cortes@ucr.ac.cr \\ 4. Centro de Investigación en Estructuras Microscópicas (CIEMIC), Universidad de Costa Rica, San Pedro, San José \\ 11501-2060, Costa Rica. \\ 5. Escuela de Biología, Universidad de Costa Rica, San Pedro, San José 11501-2060, Costa Rica. \\ 6. DeepSee, UnderSea Hunter Group, San José, Costa Rica.
}

Received 05-III-2014. Corrected 14-V-2014. Accepted 13-V-2015.

\begin{abstract}
The shallow waters around Isla del Coco, Costa Rica, have the highest density of apex predators within the Eastern Tropical Pacific. This represents a unique opportunity to assess the structure of predatory interactions in a community relatively unimpacted by fishing. Facilitation of predation has commonly been observed in shallow reef systems, limited in depth by observations via scuba divers. Here we present a preliminary catalog of facilitative behavioral interactions between 12 taxa of deepwater piscivores at Isla del Coco and Las Gemelas Seamount in the Eastern Tropical Pacific, collected via video from submersible vehicles to depths of approximately $311 \mathrm{~m}$ from 2002-2012. Observations were ad hoc and likely represent only a portion of the web of interactions that occur in this ecological setting. That such interactions can be observed to $300 \mathrm{~m}$ during the narrow time frame of submersible dives suggests that direct behavioral facilitation of piscivory may play a significant role in the apex predator guild of deepwater fishes. Investigating the extent and populationcommunity consequences of such interactions will provide valuable insight into patterns and processes that occur in communities protected from direct fisheries as well as focus conservation actions. Rev. Biol. Trop. 64 (Suppl. 1): S187-S196. Epub 2016 February 01.
\end{abstract}

Key words: behavior webs, group foraging, predation, Eastern Tropical Pacific, submersible, ROV.

Single and mixed species groups of piscivores associated with precipitous habitats (e.g., coral reef, ledge, rock wall) can have strong behavioral linkages regarding prey capture, due in part to processes that aggregate prey species when feeding and escaping predators (Hobson, 1968; Thresher, 1983; Sancho, 2000; Auster, 2008; Stallings, \& Dingeldein, 2012; Auster et al., 2013b). For example, predators may exhibit group and cooperative hunting behaviors due both to their spatial co-occurrence and focus on particular aggregations of prey or those habitats in which prey find cover (Scharf,
Buckel, McGinn, \& Juanes, 2003; Buckel, \& Stoner, 2004; Auster, 2005). Understanding the behaviors of co-occurring predators and their prey can provide insight into the conditions that facilitate such linkages (Eklov, \& VanKooten, 2001). Increased understanding of these patterns and underlying processes not only enhance our knowledge of how ecological interactions vary across underwater seascapes, but can also aid conservation planning by identifying those species and habitats where such interactions significantly influence local community structure, mediate local 
patterns of diversity and potentially enhance the persistence and resilience of populations (e.g., Heithaus, Frid, Wirsing, \& Worm, 2008; Madin, Gaines, \& Warner, 2010).

Studies by Auster \& Lindholm (2002; 2008) and Auster, Semmens, \& Barber (2005, unpublished data) from tropical coral reefs in the Caribbean Sea, Indian Ocean, Coral Sea, and Gulf of California demonstrate that 40-68 $\%$ of non-cryptic reef fishes across feeding guilds exhibit some form of multi-species group foraging, indicating that group foraging is a common behavior in reef fish communities. The piscivore guild at sub-tropical "live-bottom" reefs off the southeast coast of the United States and in the eastern Gulf of Mexico have similar patterns and exhibit a complex web of facilitative behaviors that enhance prey capture (Auster, Godfrey, Watson, Paquette, \& McFall, 2009; Auster et al., 2011; 2013b). For example, $72 \%$ of predation events at reefs off the southeast United States involved interactions in which mixed-species groups cooperatively searched for, stalked and attacked common prey species (Auster et al., 2013b). These complex interactions included single and mixed species groups of pelagic piscivores attacking prey that escaped towards reefs, where demersal piscivores took advantage of ephemeral high density patches of fish, along with the confusion effect, to attack and capture these prey species.

A limited number of species are predominant in facilitative group foraging and could be targeted by management in order to preserve such interactions (e.g., Auster et al., 2013b). For example, in a behavior web for reef predators off the southeast US coast, black and bank sea bass had the greatest number of behavioral links to other piscivore species (14 links) while gag grouper had the second highest (9). In the Gulf of Mexico region, gag grouper had the greatest number of links (12) with red snapper having 8 links. The structure of both webs demonstrate that behaviors related to prey capture involves many species but relatively few species were the foci of such interactions.
A recent study concluded that the shallow waters around Isla del Coco, Costa Rica, have the highest density of apex predators within the Eastern Tropical Pacific (Friedlander et al., 2012). This setting presents a unique opportunity to assess the structure of such interactions in a community relatively unimpacted by fishing. Here we expand upon basic observations of deepwater fish community structure (Starr, Green, \& Sala, 2012) and a diversity of transient predators (Cortés et al., 2012) in the Isla del Coco region by presenting an initial set of descriptions of facilitative predation behaviors for single and mixed species groups of deepwater piscivores collected with video from underwater vehicles. Our purpose for presenting this preliminary catalog of observations beyond scuba depth (ca. $30 \mathrm{~m}$ ) is to serve as a catalyst for additional studies that will elucidate the population and community consequences of facilitative behaviors in higher trophic level predators across a gradient of both depth and fishing impacts.

\section{METHODS}

We describe facilitative behavioral interactions of single and mixed species groups of piscivores in deep water (ca. 50-300 m depth) from sites (Fig. 1) immediately surrounding Isla del Coco $\left(5^{\circ} 32.5^{\prime} \mathrm{N}-87^{\circ} 05.1^{\prime} \mathrm{W}\right)$ and the adjacent Las Gemelas Seamount area $\left(5^{\circ} 04.8^{\prime}\right.$ $\left.\mathrm{N}-87^{\circ} 38.5^{\prime} \mathrm{W}\right)$, Costa Rica. The waters of Isla del Coco are protected within the National Park whereas Las Gemelas Seamount is subject to fishing pressure within a Seamounts Management Area. Both areas are topographic highs along the crest of Coco Volcanic Cordillera (Rojas, \& Alvarado, 2012), and seafloor complexity is primarily due to historic volcanic processes (e.g., cones, fissures, collapsed lava tubes, exposed gas cavities or vacuoles).

Observations reported here are based on video records from 27 dives (ca. $50.8 \mathrm{hrs}$ ) of the DeepSee human-occupied submersible at both Isla del Coco and Las Gemelas Seamount from 2006-2012 and the Hela remotely operated vehicle from 11 dives (24.3 hrs) during 


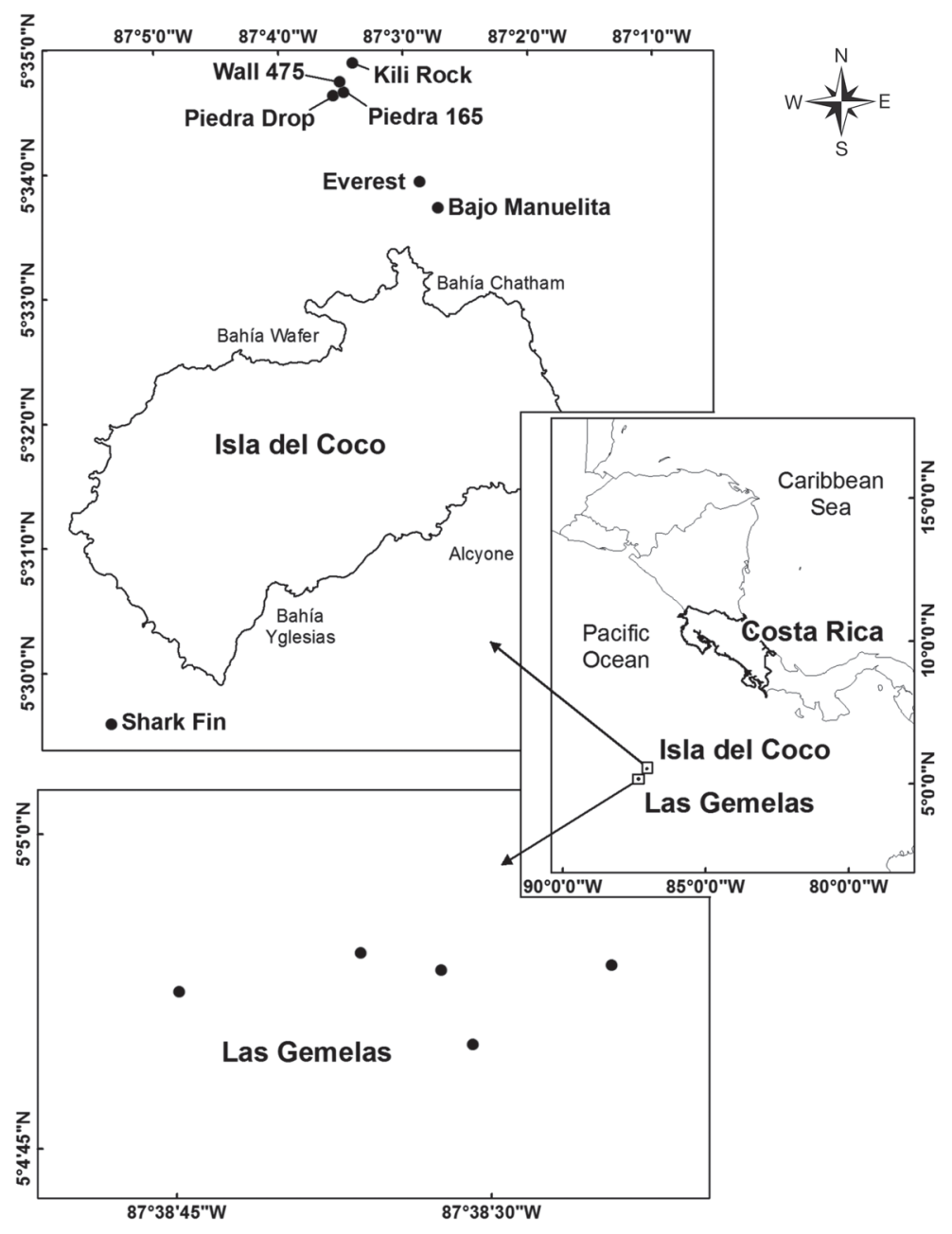

Fig. 1. Dive sites at Isla del Coco National Park and Las Gemelas Seamounts Management Area. Detailed high resolution bathymetry of this region is not available so only dive site locations are indicated. Depths at dive sites directly around Isla de Coco ranged from 50-311 m. Depths around dive sites at Las Gemelas ranged from 167-272 m.

February 2012 at Las Gemelas Seamount. None of these dives were made specifically to record facilitative behaviors or species interactions so observations reported here are essentially ad hoc. Most important to note is that these observations are not necessarily inclusive of all occurrences of such behaviors observed on these dives but only those that were recorded.

Video segments with fishes that exhibited facilitative predatory behaviors had the following characteristics: (1) two or more fishes exhibited at least one of the sequential components of predatory behaviors inclusive of search, approach, attack and capture (sensu MacNulty, Mech, \& Smith, 2007); (2) individuals exhibited non-linear swimming and oriented toward potential prey or their shelter sites; and (3) animals moved as a group. Prey capture was not required. Species composition, abundance, depth and qualitative aspects of species interactions were recorded for each occurrence.

\section{RESULTS}

Search and predation related behaviors were observed for 17 piscivore taxa in 31 
separate occurrences (Table 1). Group size ranged from 2-40 individual animals with single species groups ranging in size from 2-9 (Fig. 2). Species richness of mixed species groups ranged from 2-11. Field-marks of jacks (Carangidae) and large grouper (Serranidae) were not always visible so observations were aggregated to family level, although we do report the list of species observed. Frogfish were difficult to identify from video so we simply report those at the family level so the number of taxa involved in these types of interactions may be larger. Muraenid eels were observed but the species designation is unclear although we assume both occurrences involved a single species based on imagery. Scientific and common names are provided in Table 1 while common names are used throughout the text.

The most common occurrences of facilitative interactions involved the grouper complex of snowy, sailfin and olive grouper (Fig. 3). Such single-family groups ranged in size from 2-9 individuals. Either one individual consistently served as focal or lead animal and initially probed crevices or the role shifted with the focal animal apparently determined by the proximity of a crevice as the group moved along the seafloor. In mixed species groups (i.e., other than the taxa in the grouper complex as defined) grouper served dual roles either as the focal animal (i.e., one or more individuals provided the cues for behaviors of others) or cued to the activities of other species. For example,

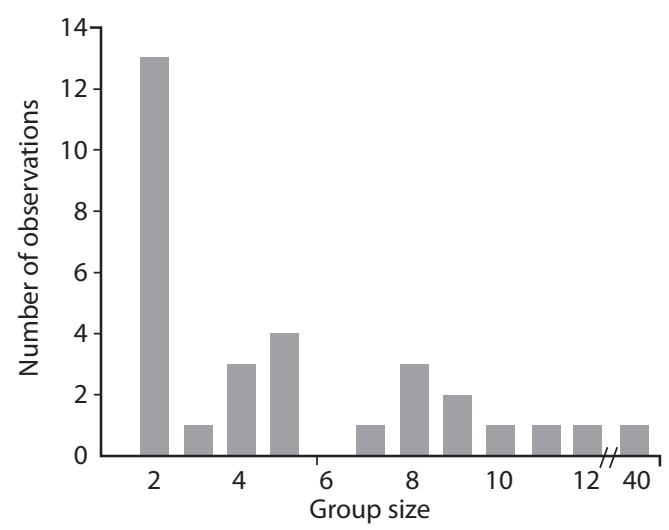

Fig. 2. Distribution of number of individuals involved in group foraging.

TABLE 1

Number of occurrences for each taxa in single and mixed species groups

\begin{tabular}{|c|c|c|c|c|c|}
\hline Species & Common name & Max. depth obs. (m) & Single sp. occ. & Mixed spp. occ. & Total occ. \\
\hline Seriola rivoliana & Almaco jack & 82 & 1 & 5 & 6 \\
\hline Antennariidae & Frogfish sp. & 300 & & 2 & 2 \\
\hline Serranidae & Grouper spp. & & 9 & 13 & 22 \\
\hline Epinephelus cifuentesi & Olive grouper & 300 & & & \\
\hline Mycteroperca olfax & Sailfin grouper & 311 & & & \\
\hline Epinephelus niphobles & Snowy grouper & 217 & & & \\
\hline Carangidae & Jack spp. & 98 & 2 & 7 & 9 \\
\hline Caranx lugubris & Black jack & & & & \\
\hline Caranx melampygus & Bluefin trevally & & & & \\
\hline Lutjanus jordani & Jordan snapper & 50 & & 1 & 1 \\
\hline Dermatolepis dermatolepis & Leather bass & 82 & & 2 & 2 \\
\hline Bodianus diplotaenia & Mexican hogfish & 98 & & 5 & 5 \\
\hline Muraenid sp. & Moray & 311 & & 3 & 3 \\
\hline Echinorhinus cookei & Prickly shark & 169 & & 2 & 2 \\
\hline Elagatis bipinnulata & Rainbow runner & 50 & & 1 & 1 \\
\hline Pontinus sp. & Scorpionfish sp. & 300 & 1 & 2 & 3 \\
\hline Carcharhinus falciformis & Silky shark & 50 & & 1 & 1 \\
\hline Thunnus albacares & Yellowfin tuna & 50 & & 1 & 1 \\
\hline Lutjanus argentiventris & Yellowtail snapper & 50 & & 2 & 2 \\
\hline
\end{tabular}



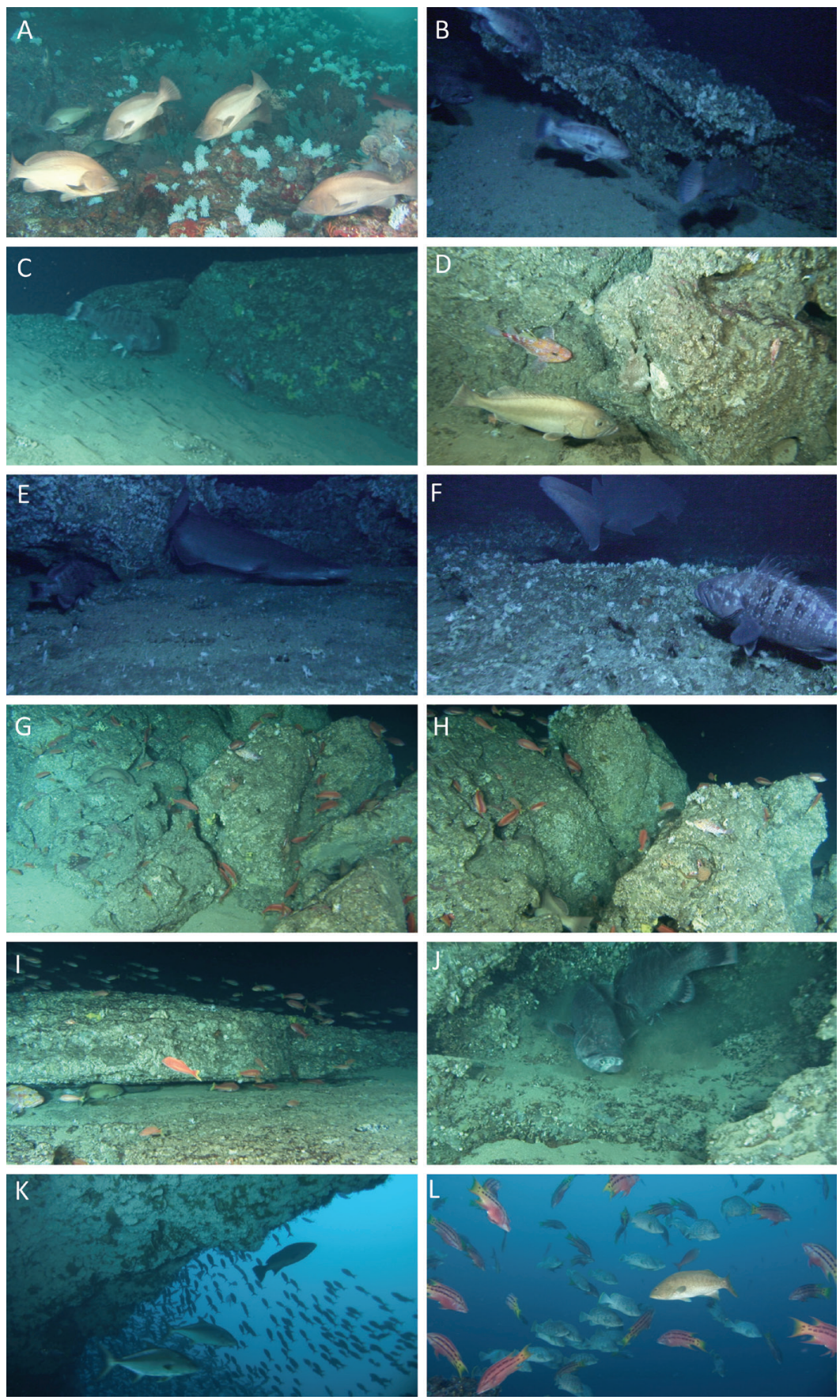

Fig. 3. Examples of behavioral interactions within the grouper complex. (A) Single species aggregation of olive grouper moving over seafloor and probing crevices for potential prey, (B) Mixed species aggregation of snowy and sailfin grouper, switching roles as focal or follower, (C) Sailfin grouper following scorpionfish, (D) Olive grouper and scorpionfish moved to orient to frogfish waving it's illicium to attract prey, (E) and (F) Sailfin grouper following prickly shark along line of crevices, (G) and (H) Moray searching through crevices and followed into crevice by a grouper, (I) Olive grouper following a moray in a long narrow crevice, (J) Two sailfin grouper in crevice after focal animal attacked and captured fish prey, (K) Almaco jack following grouper along arch, (L) Grouper using resting schools of leather bass and Mexican hogfish as camouflage. 
groupers followed individual moray eels (the focal animal) as the eel searched through crevices under boulder size rocks and within cracks and vents in the basalt foundation. Groupers were also observed moving toward and orienting to the movement of scorpionfish as the focal animal, then maintaining position or following slowly. Groupers, and in one occurrence together with a scorpionfish, moved and oriented to frogfish on the seafloor who were actively employing their illicium to attract prey, inferred by the proximate aggregations of small Anthiinae and their attraction to such movements (Anthiinae species complex sensu Starr et al., 2012). Groupers also followed prickly sharks for short distances (ca. 10-20 m) along habitats that included deep crevices.

In all of these cases we infer that these were strategies to facilitate prey capture via ambush when a focal animal disturbs (e.g., other grouper, moray, prickly shark) or lures prey (e.g., frogfish), or when from a failed ambush (e.g., scorpionfish). Mixed species groups with grouper as focal species included black jack, Mexican hogfish and Almaco jack as followers. In the latter case, this occurred when groupers searched within aggregations of potential prey above the seafloor. Movement of fishes was generally along edges (e.g., crest of ridge, base of ridge or slope, within the topographic lows of lava channels or collapsed lava tubes, and along edges formed by attached fauna, such as a line of octocoral colonies).

Six leather bass and a Mexican hogfish were observed following an octopus as it moved using its arms to probe along the seafloor (Fig. 4A). Black jack were followed short distances by Mexican hogfish (Fig. 4B) as the former investigated spaces between densely attached fauna (e.g., corals). Both black jack and bluefin trevally used movements of large transient animals (i.e., whale shark Rhincodon typus, giant manta Manta birostris), and aggregations of planktivores (i.e., Pacific creolefish Paranthias colonus) as camouflage for searching and apparently to transit to areas of the reef or water column to initiate search and approach behaviors (Figs. 4C, D).

The largest mixed species group of piscivores in terms of both species richness $(S=11)$
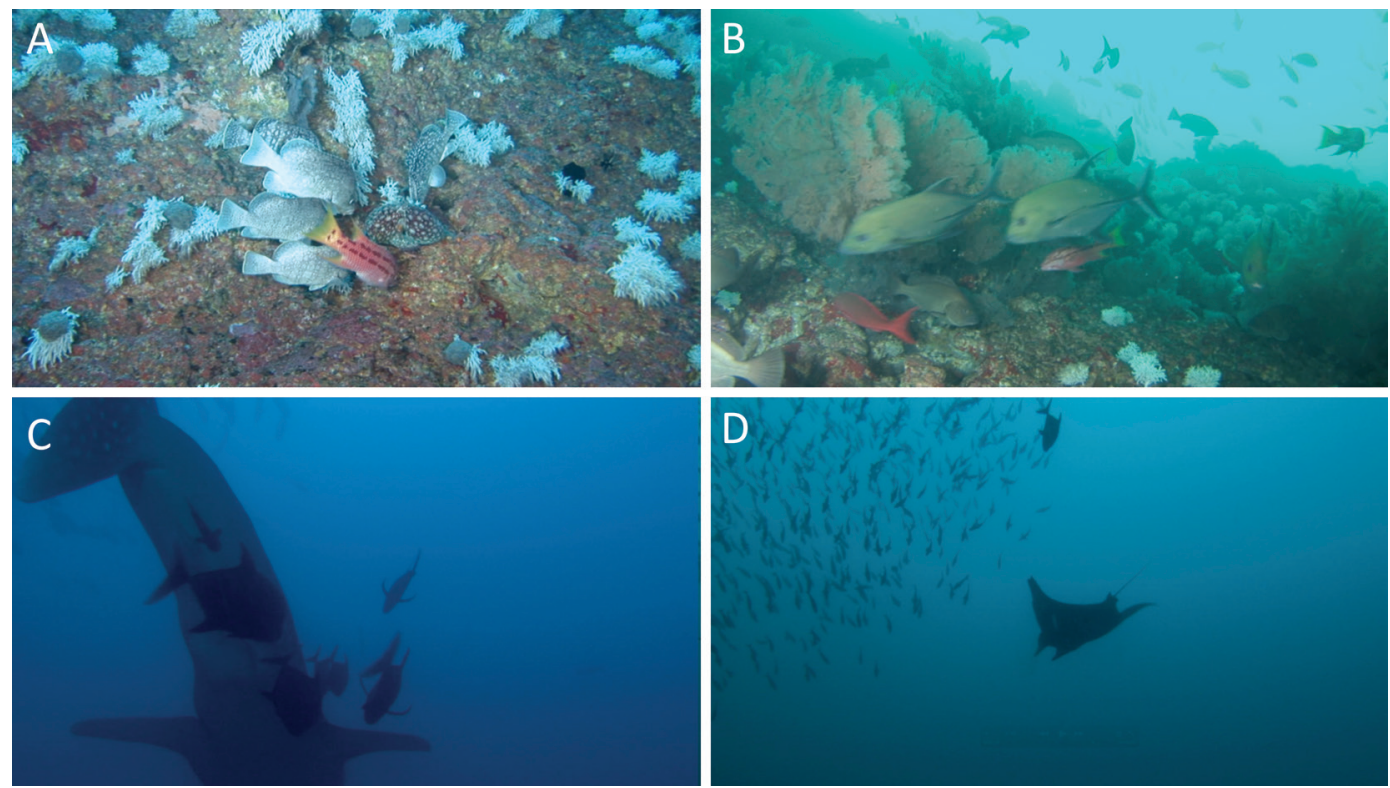

Fig. 4. Examples of other types of group interactions. (A) Leather bass and Mexican hogfish following octopus as focal animal, (B) Mexican hogfish following a pair of black jack over a short distance amongst coral habitat, (C) Jacks following a whale shark for camouflage to approach and attack school of creolefish, (D) Jack leaving proximity of ray to approach and attack school of creolefish. 
and numbers of individuals $(\mathrm{n}=40)$ was focused on attacking an aggregation of approximately 50 juvenile rainbow runner (Elagatis bipinnulata) on a small (10 m diameter) basalt peak at approximately $50 \mathrm{~m}$ depth (Fig. 5). The prey were split into smaller groups and attacked by individual predators. The prey species again aggregated into a single large group during breaks in attacks. Predation was ongoing when first observed with sequential sets of attacks continuing over approximately $45 \mathrm{~min}$. At least three silky shark and five yellowfin tuna were observed attacking the aggregation at the seafloor in an ad hoc manner and consuming prey. Four Almaco jacks, two black jacks and one rainbow runner (adult) joined the tunas and sharks in the sequence of attacks. Thirteen leather bass, two Jordan snapper, two Mexican hogfish, six olive grouper, one muraenid eel and one yellowtail snapper oriented to the prey along the periphery of the area where the large tunas and sharks were focusing their attacks at the seafloor, moving to the center of predation activity after attacks by larger animals. Two successful attacks and captures by leather bass were observed. The continued presence of sharks and tunas in the water column above the peak and multiple species of piscivores along
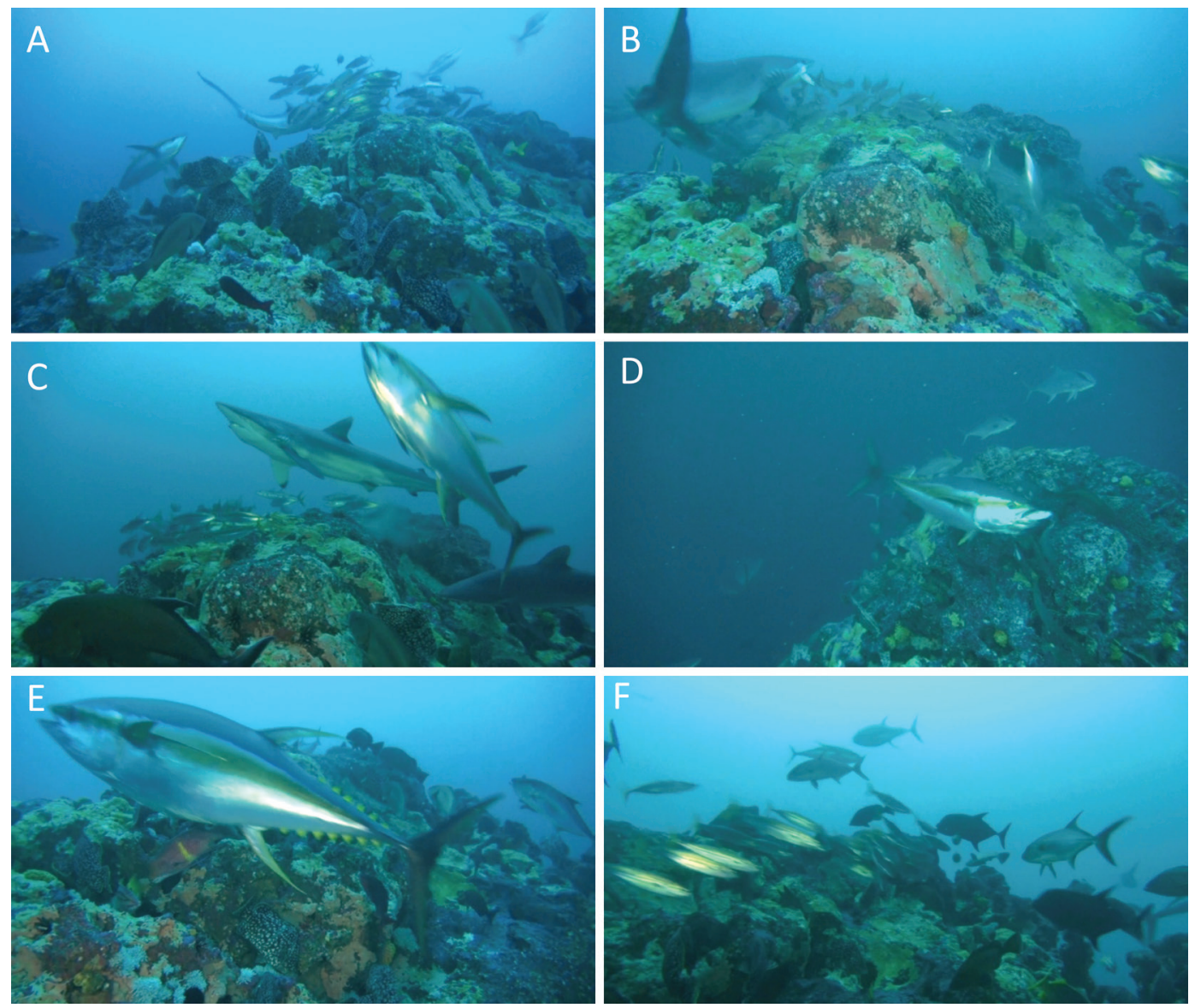

Fig. 5. Mixed species predation on a school of juvenile rainbow runner. (A) Silky shark and yellowfin tuna maneuvering at peak to attack prey. Note olive grouper, leather bass, Jordan snapper, moray, Mexican hogfish and yellowtail snapper along deeper margin of school, (B) Attack by silky shark on the aggregated school of prey, (C) Another shark attack with tuna proximate. Note black jack in maneuvering group in lower left (black jack also directly attacked school later in this event), (D) Attack by yellowfin tuna. Note approach by multiple Almaco jack, (E) Olive grouper at peak as tuna and other species circle the summit after departure of sharks from the immediate area, (F) Multiple black jack attacking school. 
the upper slope apparently prevented a flight response and kept the juvenile rainbow runner confined and circling this small area and facilitated these multiple attacks.

\section{DISCUSSION}

We have described a diversity of single and mixed species group behaviors of piscivorous fishes searching and hunting (foraging) in deep water, at least to a depth of $311 \mathrm{~m}$, in the Isla del Coco region of the Eastern Tropical Pacific. That these types of interactions extend to such depths is not necessarily surprising given that the depth distribution of some species transcend shallow $(<30 \mathrm{~m})$ to deep communities and behavioral facilitation is relatively common in shallow settings. However, it is notable that these species exhibit facilitative behaviors in these deeper environmental settings. We infer that fitness benefits are increased by investing in these behaviors (e.g., increased prey capture rates with concomitant effects on physiological condition, growth, and fecundity; Lukoschek, \& McCormick, 2002).

Variation in group size suggests that while small groups may be most common, large groups are not necessarily an impediment to the benefits of group hunting. Experimental studies indicate that per capita prey capture rates of fishes in single species groups of piscivores increase with larger group size but only to a threshold, and thereafter per capita capture rates decline (Buckel, \& Stoner, 2004). While all of the taxa we describe in this study are in the piscivore guild, different species use different strategies for prey capture, operate in heterogeneous habitats, and perhaps produce some overall efficiencies for prey capture. The role of behavioral shifts in prey based on variable assessment of predation risk, and the responses possible in mixed species groups of predators, may provide a useful framework for future studies (Lima, 2002; Lima, \& Dill, 1990; Madin et al., 2010).

What we are missing in this study is quantification of time budgets of each association (e.g., Barber, \& Auster, 2005) and rates of occurrence of these behaviors due to the post-hoc nature of these observations and use of video that was collected for other purposes. However, these observations establish a foundation for future studies on the strength of behavioral interactions within and between species; feeding, growth and fecundity of key species; and the effects of species removals by fishing and other forms of direct and indirect disturbance on these behavior webs. From a practical perspective, ecosystem approaches to ocean management will need to account for those species interactions that drive variation in growth and survivorship at the scale at which management occurs (or should occur) and identify those species whose influence is critical but not necessarily perceptible with traditional approaches (Auster et al., 2013a; Travis et al., 2014).

\section{ACKNOWLEDGMENTS}

The authors thank the masters and crews of the MV Argo and Sea Hunter and the pilots and technicians of the DeepSee submersible (Undersea Hunter Group) and Hela ROV (NURTEC at University of Connecticut). The 2012 expedition to Las Gemelas Seamount was supported by the National Geographic Society, U.S. National Science Foundation (Grant DRL1114251), Akiko Shiraki Dynner Fund for Ocean Exploration, New England Aquarium, Conservation International and University of Connecticut. Special thanks to Greg Stone and Brian Skerry for inviting PJA and JC to participate in this expedition. JC acknowledges the support by the Vicerrectoría de Investigación (project 808-B0-654) and CIMAR, Universidad de Costa Rica. The opinions expressed herein are those of the authors and do not necessarily reflect those of the funding and support organizations and agencies. This is contribution 241 to Sea Research Foundation.

\section{RESUMEN}

Las aguas someras alrededor de la Isla del Coco, Costa Rica, tienen la densidad más alta de depredadores 
tope del Pacífico Tropical Oriental (PTO). Esto representa una oportunidad única para estudiar la estructura de interacciones de depredadores en un sitio no impactado por la pesca. Facilitación de depredación ha sido observada en ambientes arrecifales someros, limitado a la profundidad de observación de buzos con tanques de buceo (scuba). Aquí presentamos un catálogo preliminar de interacciones de comportamientos facilitativos entre 12 taxones de piscívoros de aguas profundas de la Isla del Coco y el Monte Submarino Las Gemelas en el PTO. Esto se hizo analizando videos tomados con vehículos sumergibles hasta una profundidad de $311 \mathrm{~m}$ entre el 2002 y el 2012. Las observaciones fueron ad hoc y probablemente representan solo una fracción de las redes de interacciones que se dan en estos ambientes. El que estas observaciones se puedan observar hasta más de $300 \mathrm{~m}$, en períodos de tiempo muy cortos de las inmersiones con sumergibles, sugieren que el comportamiento facilitativo directo debe jugar un rol importante para los depredadores tope de aguas profundas. Investigando el alcance y las consecuencias en poblaciones-comunidades de tales interacciones pueden proveer valiosas perspectivas sobre patrones y procesos que se dan en comunidades protegidas de la pesca directa como también para enfocar acciones de conservación.

Palabras clave: redes de comportamiento, grupos de forrajeo, depredación, Pacífico Tropical Oriental, sumergible, Vehículos de Operación Remota.

\section{REFERENCES}

Auster, P. J. (2005). Predatory behavior of piscivorous reef fishes varies with changes in landscape attributes and social context: integrating natural history observations in a conceptual model. p. 115-127. In: Diving for Science 2005, Proceedings of the American Academy of Underwater Sciences. Groton, Connecticut: Connecticut Sea Grant.

Auster, P. J. (2008). Variation in search and predatory attack behaviors of shark mackerel Grammatorcynus bicarinatus. Journal of the Marine Biological Association of the United Kingdom, 88, 847-849.

Auster, P. J., \& Lindholm, J. (2002). Pattern in the local diversity of coral reef fishes versus rates of social foraging. Caribbean Journal of Science, 38, 263-266.

Auster, P. J., \& Lindholm, J. (2008). Variation in social foraging by fishes across a coral reef landscape. Proceedings of the 11th International Coral Reef Symposium, Fort Lauderdale, 1, 286-290.

Auster, P. J., Semmens, B., \& Barber, K. (2005). Pattern in the co-occurrences of fishes inhabiting the coral reefs of Bonaire, Netherlands Antilles. Environmental Biology of Fishes, 74, 187-194.
Auster, P. J., Godfrey, J., Watson, A., Paquette, A., \& McFall, G. (2009). Prey behavior links midwater and demersal piscivorous reef fishes. Neotropical Ichthyology, 7, 109-112.

Auster, P. J., Grenda, D., Godfrey, J., Heupel, E., Auscavitch, S., \& Mangiafico, J. (2011). Behavioral observations of Lilliputian piscivores: young-of-year Sphyraena barracuda at offshore sub-tropical reefs (NW Atlantic Ocean). Southeastern Naturalist, 10, 563-569.

Auster, P. J., Estes, J. A., \& Coleman, F. C. (2013a). Species interactions in marine communities: the invisible fabric of nature. Bulletin of Marine Science, 89, 3-9.

Auster, P. J., Kracker, L., Price, V., Heupel, E., McFall, G., \& Grenda, D. (2013b). Behavior webs of piscivores at subtropical live-bottom reefs. Bulletin of Marine Science, 89, 377-396.

Barber, K., \& Auster, P. J. (2005). Patterns of mixedspecies foraging and the role of goatfish as a focal species. In Proceedings of the American Academy of Underwater Sciences (Ed.), Diving for Science 2005 (pp. 108-114). Groton, Connecticut: Connecticut Sea Grant.

Buckel, J. A., \& Stoner, A. W. (2004). Negative effects of increasing group size on foraging in two estuarine piscivores. Journal of Experimental Marine Biology and Ecology, 307, 183-196.

Cortés, J., Sánchez-Jiménez, A., Rodríguez-Arrieta, A., Quirós-Barrantes, G., González, P. C., \& Blum, S. (2012). Elasmobranchs observed in deep waters (45-330m) at Isla del Coco National Park, Costa Rica (Eastern Tropical Pacific). Revista de Biología Tropical, 60(Supplement 3), 257-273.

Elkov, P., \& VanKooten, T. (2001). Facilitation among piscivorous predators: effects of prey habitat use. Ecology, 82, 2486-2494.

Friedlander, A. M., Zgliczynski, B. J., Ballesteros, E., Aburto-Oropeza, O., \& Sala, E. (2012). The shallowwater fish assemblage of Parque Nacional Isla del Coco, Costa Rica: structure and patterns in an isolated, predator-dominated ecosystem. Revista de Biología Tropical, 60(Supplement 3), 321-338.

Heithaus, M., Frid, A. Wirsing, A., \& Worm, B. (2008). Predicting ecological consequences of marine top predator declines. Trends in Ecology and Evolution, 23, 202-210.

Hobson, E. S. (1968). Predatory behavior of some shore fishes in the Gulf of California. Research Report U.S. Fish Wildife Service, 73, 1-92.

Lima, S. L. (2002). Putting predators back into behavioral predator-prey interactions. Trends in Ecology and Evolution, 17, 70-75. 
Lima, S. L., \& Dill, L. M. (1990). Behavioral decisions made under risk of predation: A review and prospectus. Canadian Journal of Zoology, 68, 619-640.

Lukoschek, V., \& McCormick, M. I. (2002). A review of multi-species foraging associations in fishes and their ecological significance. Proceeding of the 9th International Coral Reef Symposium, Bali, Indonesia, $1,467-474$.

MacNulty, D. R., Mech, L. D., \& Smith, D. W. (2007). A proposed ethogram of large-carnivore predatory behavior, exemplified by the wolf. Journal of Mammalogy, 88, 595-605.

Madin, E. M. P., Gaines, S. D., \& Warner, R. R. (2010). Field evidence for pervasive indirect effects of fishing on prey foraging behavior. Ecology, 91, 3563-3571.

Rojas, W., \& Alvarado, G. E. (2012). Geología y contexto geotectónico de la Isla del Coco y la zona marítima frente al Pacífico central de Costa Rica. Revista de Biología Tropical, 60(Supplement 3), 15-32.

Sancho, G. (2000). Predatory behaviors of Caranx melampygus (Carangidae) feeding on spawning reef fishes: a novel ambushing strategy. Bulletin of Marine Science, 66, 487-496.
Scharf, F. S., Buckel, J. A., McGinn, P. A., \& Juanes, F. (2003). Vulnerability of marine forage fishes to piscivory: effects of prey behavior on susceptibility to attack and capture. Journal of Experimental Marine Biology and Ecology, 294, 41-59.

Stallings C. D., \& Dingeldein, A. L. (2012). Intraspecific cooperation facilitates synergistic predation. Bulletin of Marine Science, 88, 317-318.

Starr, R. M., Green, K., \& Sala, E. (2012). Deepwater fish assemblages at Isla del Coco National Park and Las Gemelas Seamount, Costa Rica. Revista de Biología Tropical, 60(Supplement 3), 347-362.

Thresher, R. E. (1983). Environmental correlates of the distribution of planktivorous fishes in the One Tree Reef lagoon. Marine Ecology Progress Series, 10, 137-145.

Travis, J., Coleman, F. C., Auster, P. J., Cury, P. M., Estes, J. A., Orensanz, J., Peterson, C. H., Power, M. E., Steneck, R. S., \& Wootton, J. T. (2014). Integrating the invisible fabric of nature into fisheries management. Proceedings of the National Academy of Science, U.S.A., 111, 581-584. 